\title{
KEANEKARAGAMAN DAN KELIMPAHAN JENIS TERIPANG DI PANTAI LANDU, PULAU LANDU, KABUPATEN ROTE NDAO
}

\section{(DIVERSITY AND ABUNDANCE OF SEA CUCUMBER TYPES IN LANDU BEACH, LANDU ISLAND, ROTE NDAO DISTRICT)}

\author{
Alefane Ndun*, Yanti Daud, dan Arnold Christian Hendrik \\ Program Studi Pendidikan Biologi, Universitas Kristen Artha Wacana
}

\begin{abstract}
Keywords:

Landu Island, Landu beach is a beach located on Landu Island, Southwest Rote District, Rote Ndao Holothuroidea, Diversity of Sea cucumber, abundance of Sea cucumber Regency, the southernmost district in Indonesia. Sea cucumbers are used by the coastal community of Landu Beach as food and sold to the market as a source of income. So far, it is not scientifically known the types of sea cucumbers and the level of sea cucumber diversity in the coastal waters of Landu. Therefore, this study aims to identify the diversity and abundance of sea cucumbers on research site. This study used a survey method with the sampling technique using the quadratic transect method (quadrant transect method). With five transects, each transect consists of 5 plots. The data taken were in the form of sea cucumber species, the number of sea cucumbers per plot, and the state of the substrate per observation plot. The Study results found four types of sea cucumber species in Landu Beach, namely Holothuria scabra, $H$. arata, H.leucospilota, and Bohadchia marmorata. The abundance of every kind of sea cucumber found was Holothuria scabra with the highest abundance value, namely $2.44 \mathrm{ind} / \mathrm{m} 2$ followed by Holothuria arta $(2.16 \mathrm{ind} / \mathrm{m} 2)$, Bohadchia marmorata (1.92 ind / m2), and H.leucospilota (1.68 ind. / m2). Bohadchia marmorata species has a frequency of 1.0 , which means this species was found in the research plot seedlings. The following frequency values are Holothuria scabra $(0.72), H$. arta $(0.68)$, and the lowest frequency value is $H$. leucospilota $(0.60)$. The Shannon-Wiener $\left(H^{\prime}\right)$ diversity index value of sea cucumbers on Landu Beach is 1.37, so that the diversity of sea cucumbers on Landu Beach is in the medium diversity category.
\end{abstract}

Kata Kunci:

Pulau landu, Holothuroidea, keanekaragaman teripang, kelimpahan teripang

\section{ABSTRAK}

Pantai landu merupakan pantai yang terdapat di Pulau Landu, Kecamatan Rote Barat Daya, Kabupaten Rote Ndao, yang merupakan kabupaten terselatan di Indonesia. Teripang oleh masyarakat pesisir Pantai Landu dimanfaatkan sebagai bahan makanan dan dijual ke pasar sebagai sumber penghasilan. Sejauh ini belum diketahui secara ilmiah jenis-jenis teripang dan tingkat keanekaragaman teripang di perairan pantai Landu. Karena itu penelitian ini bertujuan untuk mengindetifikasi keanekaragaman dan kelimpahan jenis teripang di lokasi penelitian. Penelitian ini menggunakan metode survei dengan teknik pengambilan sampel menggunakan metode transek kuadrat (kuadran transect method). Dengan jumlah transek sebanyak 5, masing-masing transek terdiri dari 5 plot. Data yang diambil berupa jenis teripang, jumlah teripang per plot, dan keadaan substrat per plot pengamatan. Hasil penelitian menemukan 4 jenis spesies teripang di Pantai Landu antara lain Holothuria scabra, $H$. arata, H. leucospilota, dan Bohadchia marmorata. Kelimpahan setiap jenis teripang yang ditemukan yaitu $H$.Scabra dengan nilai kelimpahan tertinggi yaitu $2,44 \mathrm{ind} / \mathrm{m}^{2}$, diikuti Holothuria Arta $\left(2,16 \mathrm{ind} / \mathrm{m}^{2}\right)$, Bohadchia Marmorata $\left(1,92 \mathrm{ind} / \mathrm{m}^{2}\right)$, dan $H$. Leucospilota $\left(1,68 \mathrm{ind} / \mathrm{m}^{2}\right)$. spesies Bohadchia Marmorata memiliki frekuensi 1,0 yang artinya spesies ini ditemukan di semai plot penelitian. Nilai frekuensi selanjutnya yaitu $H$. Scabra $(0,72)$, Holothuria Arta $(0,68)$, dan nilai frekuensi terendah yaitu $H$. Leucospilota $(0,60)$. Nilai indeks keanekaragaman Shannon-Wiener $\left(\mathrm{H}^{\prime}\right)$ teripang di Pantai Landu yaitu 1,37, sehingga keanekaragamn teripang di Pantai Landu termasuk kategori keanekaragaman sedang.

Corresponding Author: Arnold hendrik@yahoo.co.id 


\section{PENDAHULUAN}

Pantai landu merupakan pantai yang terdapat di Pulau Landu, Kecamatan Rote Barat Daya, Kabupaten Rote Ndao. Kabupaten Rote Ndao merupakan salah satu kabupaten terluar di Indonesia, kabupaten ini terselatan di Indonesia. Pulau Landu memiliki panjang garis pantai $\pm 2 \mathrm{~km}$, karakteristik wilayah ini umumnya datar, memiliki substrat berpasir, dan pasir berbatu. Hampir seluruh masyarakat di wilayah Desa Landu menggantungkan hidupnya pada sektor hasil laut. Masyarakat di pesisir Pantai Landu yang memanfaatkan hasil laut seperti ikan, kerang, teripang, dan rumput laut untuk kebutuhan sehari-hari maupun untuk dijual.

Teripang oleh masyarakat pesisir Pantai Landu dimanfaatkan sebagai bahan makanan dan dijual ke pasar sebagai sumber penghasilan. Teripang diketahui memiliki nilai ekonomis karena dapat dimanfaatkan sebagai bahan pangan, memiliki kandungan yang dapat dimanfaatkan dalam bidang farmasi, \& kosmetika (Handayani et al, 2017; Oedjoe \& Eoh, 2015; Sukmiwati et al., 2012). . Teripang (Apostichopus Japonicas) dipercaya oleh masyarakat Tiongkok sejak dahulu sebagai salah satu bahan yang memiliki fungsi medis, salah satunya untuk meningkatkan spermatogenesis (Xia \& Wang, 2015; Yang \& Bai, 2015). Teripang juga dapat dimanfaatkan ekstraknya dan dijadikan tonik contohnya minyak gamat di Malaysia (Zamora et al, 2015). Selain itu Teripang dianggap sebagai makanan laut premium karena rasio protein dan lipidnya yang tinggi, mengandung asam lemak tak jenuh yang sangat bermanfaat, asam amino esensial, kolagen, vitamin dan mineral (Wen et al., 2010; Lee et al., 2012).

Nilai ekonomis teripang tersebut menjadikan teripang merupakan salah satu komoditas eksport perikanan Indonesia. Nilai eksport teripang Indonesia dari Tahun 2015-2019 terus mengalami peningkatan per tahunnya nilainya berkisar 6.368.588 USD (tahun 2015) sampai 16.398.784 USD (tahun 2019) (Kementerian Kelautan dan Perikanan, 2020). Dengan Negara tujuan eksport terbesar antara lain ke Tiongkok, Singapore, dan Korea Selatan

Jenis teripang yang memiliki nilai ekonomis tinggi untuk dieksport antara lain meliputi famili Holothuriidae dan Stichopodidae, meliputi genus Holothuria, Actinopyga, Bohadschia, Thelenota dan Stichopus (Darsono, 2007). Terdapat 2 jenis teripang dengan nilai ekonomi tinggi yaitu Apostichopus japonicus dan Holothuria scabra, sehingga 2 jenis teripang ini diketahui telah dibudidayakan untuk tujuan komersil (Hair et al., 2012; Yang et al., 2015; Ru et al., 2018). Tingginya permintaan pasar terhadap teripang untuk kebutuhan eksport membuat eksploitasi berlebih terhadap teripang tak terhindarkan 
(Handayani et al., 2017). Daur hidup teripang yang spesifik menjadikan teripang sangat rentan oleh terjadinya tangkap lebih, sekali populasi teripang turun maka sulit untuk pulih kembali (Darsono, 2007).

Teripang seperti yang disebutkan sebelumnya merupakan salah satu komoditi laut yang dimanfaatkan oleh masyarakat pesisir Pantai Landu. Sejauh ini belum diketahui secara ilmiah jenis-jenis teripang dan tingkat keanekaragaman teripang di perairan pantai Landu. Ditambah lagi belum adanya peraturan spesifik yang membatasi penangkapan dan perdagangan teripang dari perairan Pantai Landu, sehingga menjadi permasalahan penting dalam upaya menjaga kelangsungan hidup teripang, maka diperlukan berbagai upaya untuk menjaga kelestarian teripang di perairan Pantai Landu antara lain dengan tersedianya data biologi terkait jenis teripang yang terdapat di Pantai Landu. Karena itu penelitian ini bertujuan untuk mengindetifikasi keanekaragaman dan kelimpahan jenis teripang di Pantai Landu, Pulau Landu, Kabupaten Rote Ndao.

\section{BAHAN DAN METODE}

\section{Waktu dan tempat penelitian}

Penelitian ini dilaksanakan pada bulan Oktober 2019 sampai dengan bulan Februari 2020, di Pantai Landu Desa Landu Kecamatan Rote Barat Daya Kabupaten Rote Ndao (Gambar 1).

mengukur suhu perairan, refraktometer digunakan untuk mengukur salinitas, kertas

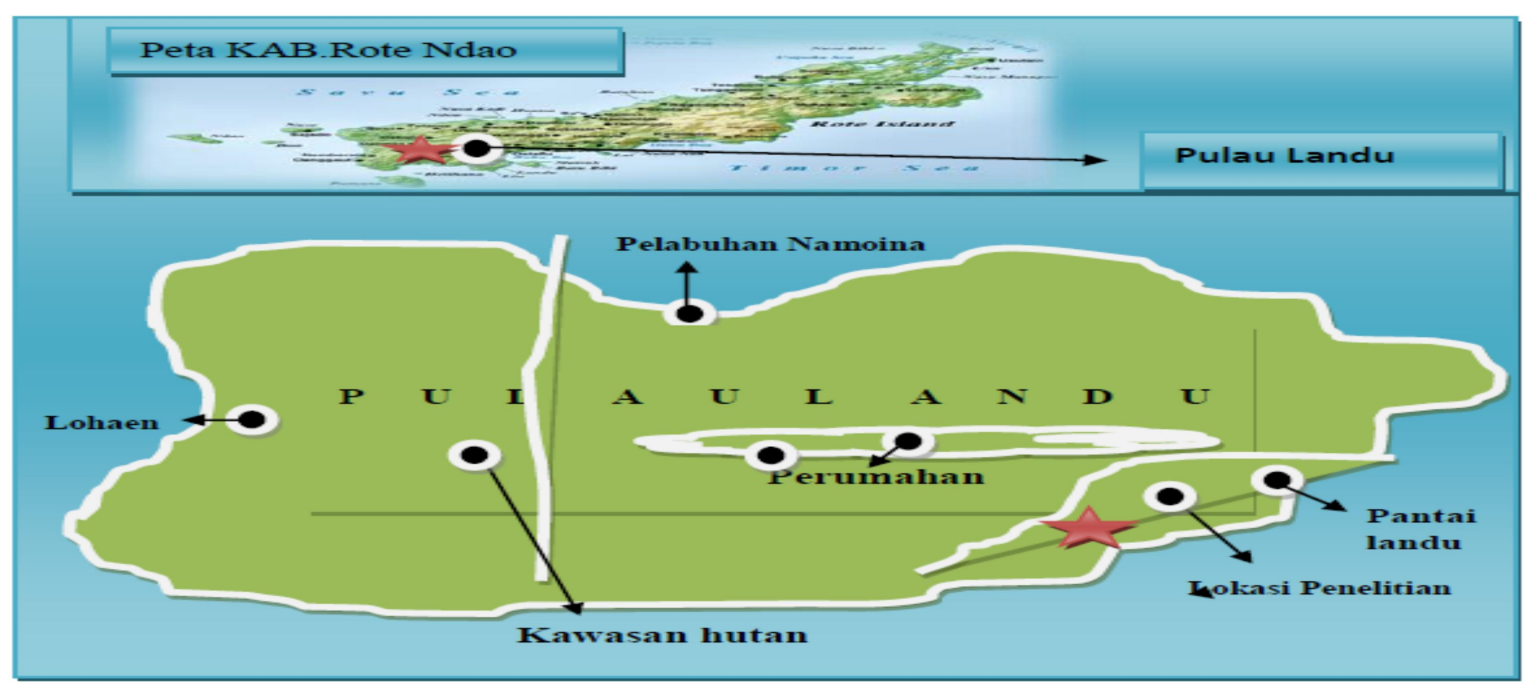

Gambar 1 Peta Lokasi Penelitian (Berikan Sumber gambar)

\section{Alat dan Bahan}

Alat yang digunakan dalam penelitian ini, yaitu: termometer digunakan untuk lakmus digunakan untuk mengukur $\mathrm{pH}$ air laut, pipa paralon digunakan untuk membuat plot, Roll meter digunakan untuk 
membuat garis transek, kamera digital (Nikon DXVR D5200) digunakan untuk dokumentasi pengambilan data, alat tulis digunakan untuk mencatat jenis Teripang yang ditemukan. Bahan yang digunakan dalam penelitian adalah sampel Teripang yang ditemukan.

\section{Metode Penelitian}

Penelitian ini menggunakan metode survei dengan teknik pengambilan sampel menggunakan metode transek kuadrat (kuadran transect method).

1. Prosedur Penelitian

Langkah awal dalam penelitian ini adalah penulis melakukan survei ke lokasi penelitian. Hal-hal yang dilakukan penulis pada tahap ini adalah mengamati situasi dan kondisi yang digunakan sebagai lokasi penelitian, kemudian menentukan lokasi peletakkan transek kuadrat. Selanjutnya penulis menyiapkan alat dan bahan yang akan digunakan dalam penelitian.

Langkah-langkah dalam pengambilan sampel Teripang pada penelitian ini antara lain: peneliti meletakan transek kuadrat yang dibuat pada lokasi penelitian yaitu pada saat surut terendah dengan menggunakan pipa paralon yang telah didesain (Gambar 2). Kemudian meletakan plot yang telah didesain dengan ukuran $1 \mathrm{~m}$ x $1 \mathrm{~m}$ mulai dari bibir pantai sampai $50 \mathrm{~m}$ ke tengah laut dengan jarak antara plot $10 \mathrm{~m}$ dan diletakkan secara berselang-seling. Jarak antara garis transek yang satu dengan yang lain $50 \mathrm{~m}$. Pada setiap plot, peneliti melakukan pengamatan terhadap semua jenis Teripang yang ada di permukaan substrat dan juga yang ada di dasar substrat. Untuk jenis Teripang yang berada dibawah permukaan tanah, dilakukan penggalian sampai kedalaman 5$10 \mathrm{~cm}$ menurut metode Dolorosa dan Galon, (2014). Total plot dalam penelitian ini adalah 25 buah yang terdiri dari 5 transek dan masing-masing transek terdiri dari 5 buah plot.

\section{Analisis Data}

1. Indeks Keanekaragaman

Tingkat keanekaragaman Teripang yang ada dalam setiap transek dapat ditentukan dengan menggunakan rumus indeks keanekaragaman Shannon-Wienner Krebs (1989) pada persamaan (2) yaitu:

$\mathrm{H}^{\prime}=-\sum P i 1 \mathrm{n} P \boldsymbol{i}$

keterangan:

$H^{\prime}=$ Indeks keanekaragaman ShannonWienner

$\mathrm{Pi}=\frac{\mathrm{ni}}{\mathrm{N}}($ Proporsi jenis $\mathrm{ke}-\mathrm{i})$ 

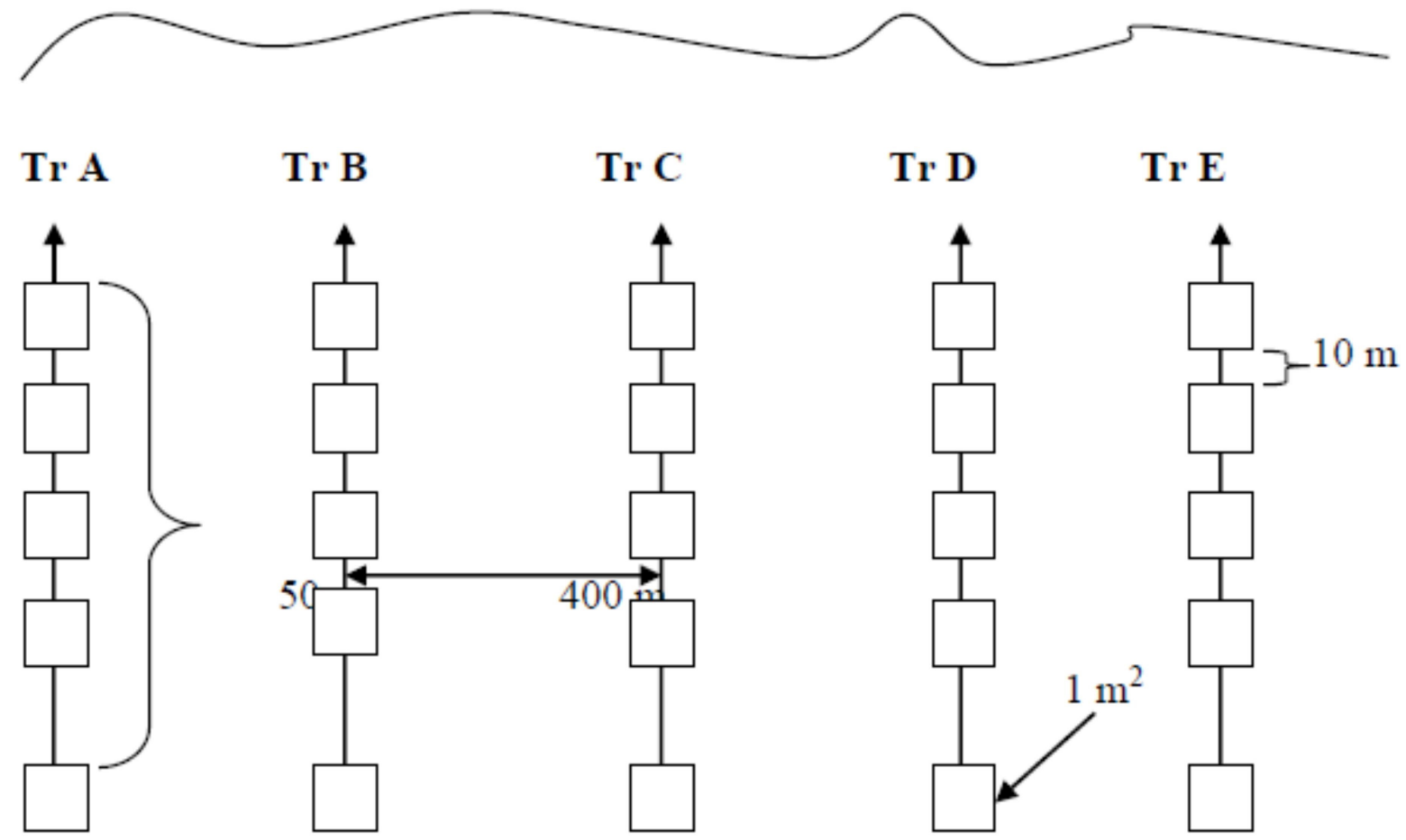

\section{$2 \mathrm{~km}$ Garis pantai}

$\mathrm{ni}=$ Jumlah individu jenis $\mathrm{ke}-\mathrm{i}$

KR : Kelimpahan Relatif

$\mathrm{N}=$ Jumlah total individu seluruh jenis

Kriteria Indeks keanekaragaman Shannon

dikategorikan atas nilai- nilai sebagai

berikut:

$H^{\prime}<1 \quad$ : Keanekaragaman jenis rendah

$1<H^{\prime}<3 \quad$ : Keanekaragaman jenis sedang

$\mathrm{H}^{\prime}>3 \quad$ : Keanekaragaman jenis tinggi

2. Kelimpahan

Untuk mengetahui kelimpahan jenis-jenis Teripang dengan menggunakan rumus dalam Odum (1993) yaitu :

$\mathrm{Di}=\frac{n i}{A}$, Keterangan

$\mathrm{Di}=$ Kelimpahan Jenis

$\mathrm{ni}=$ Jumlah Total Individu jenis ke-i

$A=$ Luas Total area pengambilan sampel

Kelimpahan Relatif ditentukan dengan rumus sebagai berikut:

$$
\mathrm{KR}=\frac{n i}{\mathrm{~N}} x 100 \%
$$

ni : Jumlah Individu

$\mathrm{N} \quad$ : Jumlah total individu

3. Frekuensi

Frekuensi (Fi)

$=\frac{\text { Jumlah plot ditemukannya suatu jenis }}{\text { Jumlah seluruh plot }}$

\section{HASIL}

Jenis teripang yang ditemukan di Pantai landu

Teripang yang ditemukan di perairan Pantai Landu terdiri dari 2 famili yaitu famili Aspidochirota dan Holothuriidae dengan total 4 spesies. Pada Tabel 1 memperlihatkan 4 jenis spesies teripang yang ditemukan di Pantai Landu antara lain Holothuria scabra, Holothuria arata, Holothuria leucospilota, dan Bohadchia marmorata. Holothuria scabra (Gambar 3a) 
dikenal oleh masyarakat Desa Landu dengan nama Nafi a'o, dan di Pantai Landu ditemukan pada substrat berkarang, pasir halus dan padang lamun. Holothuria arata (Gambar 3b) dengan nama lokal Nafi nggeok ka dak dalam penelitian ini ditemukan pada perairan dengan substrat berkarang, dan berpasir dengan terdapat lamun yang hidup. Teripang jenis Holothuria leucospilota (Gambar 3c) dengan nama lokal Nafi nggeok ta'i makadikek ditemukan dalam substrat berpasir dengan adanya lamun atau pada pantai berkarang. Bohadchia marmorata atau Nafi hadek dalam bahasa lokal (Gambar 3d), dalam penelitian ini ditemukan pada peraiaran dengan substrat padang lamun, berpasir, dan kerikil dari pecahan batu karang.

\section{Kelimpahan dan Keanekaragaman Teripang di Pantai Landu, Kabupaten Rote Ndao.}

Data kelimpahan dan nilai indeks keanekaragaman teripang di Pantai landu, disajikan dalam Tabel 1 di bawah ini. Terlihat bahwa Holothuria Scabra merupakan spesies teripang dengan nilai kelimpahan tertinggi yaitu 2, $44 \mathrm{ind} / \mathrm{m}^{2}$ diikuti Holothuria Arta $\left(2,16 \mathrm{ind} / \mathrm{m}^{2}\right)$, Bohadchia Marmorata $\left(1,92 \mathrm{ind} / \mathrm{m}^{2}\right)$, dan Holothuria Leucospilota $\left(1,68 \mathrm{ind} / \mathrm{m}^{2}\right)$. Nilai

Tabel 1. Jenis teripang yang ditemukan di Pantai Landu

\begin{tabular}{|c|c|c|c|c|}
\hline No & Family & Spesies & Nama Lokal & Substrat ditemukan \\
\hline 1 & Aspidochirota & Holothuria scabra & Nafi a'o & $\begin{array}{lll}\text { di antara } & \text { karang, } & \text { pasir } \\
\text { halus, pasir } & \text { yang } \\
\text { ditumbuhi lamun } & \end{array}$ \\
\hline 2 & Holothuriidae & Holothuria arata & Nafi nggeok ka dak & $\begin{array}{l}\text { berkarang atau berpasir } \\
\text { yang terdapat lamun }\end{array}$ \\
\hline 3 & Holothuriidae & Holothuria leucospilota & $\begin{array}{l}\text { Nafi nggeok ta'i } \\
\text { makadikek }\end{array}$ & $\begin{array}{l}\text { terumbu karang } \\
\text {,substrat berpasir dan di } \\
\text { bawah bebatuan }\end{array}$ \\
\hline
\end{tabular}
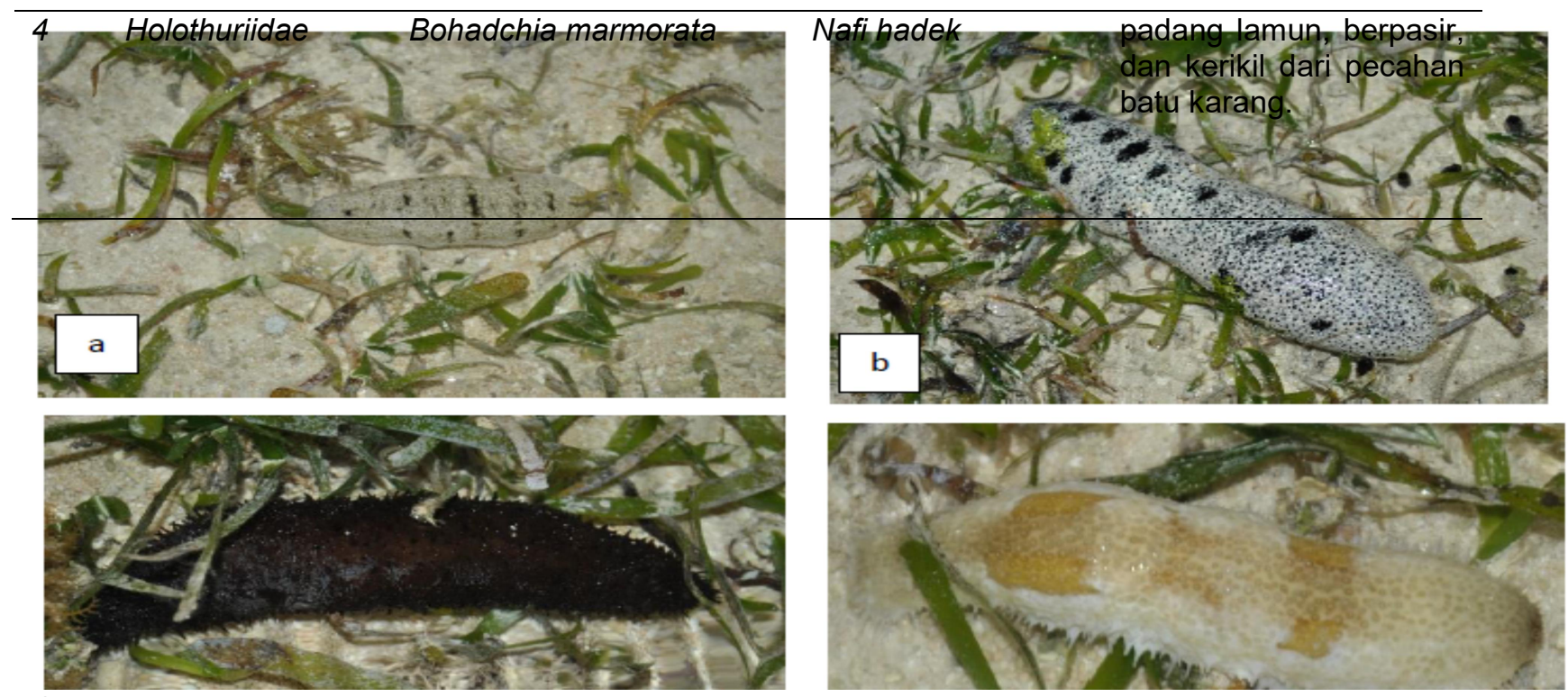

Gambar 3. Jenis-jenis Teripang di Pantai Landu. a. Holothuria scabra, b. Holothuria arata, c. Holothuria leucospilota, dan d. Bohadchia marmorata 
kelimpahan relatif Secara total kelimpahan teripang di Pantai Landu cukup tinggi mencapai $8,2 \mathrm{ind} / \mathrm{m}^{2}$. Untuk nilai frekuensi setiap spesies teripang di Pantai Landu hasil pengamatan memeperlihatkan bahwa spesies Bohadchia Marmorata memiliki frekuensi 1,0 yang artinya spesies ini ditemukan di semai plot penelitian. Nilai frekuensi selanjutnya yaitu Holothuria Scabra $(0,72)$, Holothuria Arta $(0,68)$, dan nilai frekuensi terendah yaitu Holothuria Leucospilota $(0,60)$. Untuk nilai indeks keanekaragaman menurut indeks ShannonWiener $\left(H^{\prime}\right)$ berkisar pada angka 1,37 sehingga dikategorikan bahwa Pantai Landu memiliki keanekaragam sedang.

Tabel 2. Analisis kelimpahan dan keanekaragaman populasi teripang di Pantai Landu, Kabupaten Rote Ndao.

\begin{tabular}{lllllll}
\hline No & Spesies & $\begin{array}{l}\text { Jumlah } \\
\text { individu }\end{array}$ & $\begin{array}{l}\text { Kerapatan } \\
\left(\mathrm{Ind} / \mathrm{m}^{2}\right)\end{array}$ & $\begin{array}{l}\text { KR } \\
(\%)\end{array}$ & Frekuensi & pi In pin \\
\hline 1 & Holothuria Scabra & 61 & 2,44 & 29,75 & 0.72 & -0.36 \\
\hline 2 & Holothuria Arta & 54 & 2,16 & 26,34 & 0.68 & -0.35 \\
\hline 3 & $\begin{array}{l}\text { Holothuria } \\
\text { Leucospilota }\end{array}$ & 42 & 1,68 & 20,48 & 0.6 & -0.32 \\
\hline 4 & $\begin{array}{l}\text { Bohadchia } \\
\text { Marmorata }\end{array}$ & 48 & 1,92 & 23,42 & 1.0 & -0.33 \\
\hline Total & & 205 & 8.2 & $100 \%$ & & $\mathrm{H}^{\prime}=$ \\
\hline
\end{tabular}

\section{PEMBAHASAN}

Jenis-jenis teripang yang ditemukan di Pantai Landu diketahui berada pada substrat berpasir, berlumpur, pasir halus yang ditumbuhi lamun, kerikil hasil pecahan karang, dan campuran dari substratsubstrat tersebut (berpasir, berlumpur, berbatu). Beberapa penelitian menyatakan habitat teripang di perairan dengan substrat pasir karang yang ditumbuhi lamun (Darsono, 2007; Agusta et al., 2012). Hal ini berarti kondisi substrat di perairan Pantai Landu merupakan tempat yang sesuai sebagai habitat bagi teripang. Substrat ini disukai teripang karena kebiasan makan teripang yang umumnya mengkonsumsi partikel pasir (derajat kepenuhan 80-98\%) dan algae/lamun (2-10\%) (Oedjoe dan Eoh, 2015). Teripang dalam tingkatan trofik diketahui merupakan pemakan deposit (deposit feeder) dan pemakan suspensi (suspensi feeder) (Darsono, 2007). Selain itu substrat berpasir dengan tumbuhan lamun dan karang juga merupakan tempat perlindungan bagi teripang dari predatornya (Radjab et al., 2014). 
Kondisi substrat di pantai Landu, ditambah dengan kondisi perairan yang masih baik dapat mendukung keberadaan teripang, namun demikian hanya 4 jenis teripang yang berhasil ditemukan periaran ini. Jumlah 4 jenis teripang ini lebih rendah dari jumlah 8 jenis teripang yang ditemukan di Perairan Sabu Raijua, NTT. Jumlah ini juga lebih sedikit bila dibandingkan dengan jumlah teripang yang ditemukan di beberapa perairan seperti Perairan Bagian Timur Pantai Natuna Kepulauan Riau (16 jenis), di Zona Intertidal Pantai Pancur Taman Nasional Alas Purwo (8 jenis), Perairan Kampu ng Kapisawar Distrik Meos Manswar Kabupaten Raja Ampat sebanyak 10 jenis teripang (Afrely et al., 2015; Handayani et al., 2017; Sukmiwati et al., 2012). Jumlah 4 spesies teripang yang ditemukan di Pantai Landu sama dengan yang ditemukan Perairan Taman Nasional Wakatobi, Sulawesi Tenggara (Yusron, 2016). Jumlah jenis teripang yang cenderung sedikit di Pantai landu jika dibandingkan dengan penelitian lainnya diduga karena dalam penelitian ini hanya dilakukan pengambilan sampel pada zona intertidal. Teripang sendiri diketahui dapat ditemukan sepanjang zona intertidal dangkal sampai dasar terdalam samudra, sehingga seringkali dibutuhkan menyelam untuk mendapatkannya (Woo et al., 2013; Zamora et al., 2015). Selain itu aktivitas pemanfaatan teripang yang cukup tinggi diduga dapat mempengaruhi keberadaan beberapa spesies teripang di suatu perairan. Kegiatan pengambilan teripang dari perairan berkembang sangat cepat pada beberapa perairan yang mempengaruhi jumlah teripang di perairan tersebut (Purcell et al., 2013; Anderson et al., 2011).

Teripang yang ditemukan di Pantai Landu seluruhnya dimanfaatkan masyarakat Desa Landu, baik sebagai makanan dan juga untuk dijual. Harga jual teripang oleh masyarakat Desa Landu cukup tinggi, Holothuria Scabra dijual dengan harga sekiatr Rp. 400.000/kilo kering, sedangkan jenis lainnya berkisar Rp. 150.000-250.000 per kilo kering. Berdasarkan data kelimpahan teripang terlihat bahwa masingmasing jenis teripang memiliki kelimpahan yang cukup tinggi yaitu dari $1,68 \mathrm{individu} / \mathrm{m}^{2}$ sampai 2,44 individu/ $\mathrm{m}^{2}$. Nilai keanekaragaman teripang di Pantai Landu juga tergolong kategori sedang, menandakan kondisi lingkungan di perairan Pantai Landu masih tergolong baik dalam mendukung kelimpahan populasi dari setiap jenis teripang. Dari nilai frekuensi setiap jenis teripang terlihat bahwa Bohadchia Marmorata ditemukan di setiap plot pengamatan yang berarti bahwa jenis ini terdistribusi merata di Pantai Landu. Jenis teripang Holothuria Arta memiliki kelimpahan $2,16 \mathrm{ind} / \mathrm{m}^{2}$ dengan frekuensi 0,68 menandakan jenis ini terdistribusi lebih 
dari setengah plot pengamatan dan cenderung ditemukan berkelompok.

Berdasarkan penelitian ini dapat disimpulkan bahwa ditemukan 4 jenis spesies teripang di Pantai Landu, Kabupaten Rote Ndao antara lain Holothuria scabra, Holothuria arata, Holothuria leucospilota, dan Bohadchia marmorata. Kelimpahan setiap jenis teripang yang ditemukan yaitu Holothuria Scabra dengan nilai kelimpahan tertinggi yaitu 2, $44 \mathrm{ind} / \mathrm{m}^{2}$ diikuti Holothuria Arta $\left(2,16 \mathrm{ind} / \mathrm{m}^{2}\right)$, Bohadchia Marmorata $(1,92$ ind $\left./ \mathrm{m}^{2}\right)$, dan Holothuria Leucospilota $(1,68$ ind $/ m^{2}$ ). Spesies Bohadchia Marmorata memiliki frekuensi 1,0 yang artinya spesies ini ditemukan di semai plot penelitian. Nilai frekuensi selanjutnya yaitu Holothuria Scabra $(0,72)$, Holothuria Arta $(0,68)$, dan nilai frekuensi terendah yaitu Holothuria Leucospilota $(0,60)$. Untuk nilai indeks keanekaragaman menurut indeks ShannonWiener $\left(H^{\prime}\right)$ berkisar pada angka 1,37 sehingga dikategorikan bahwa teripang di Pantai Landu memiliki keanekaragam sedang.

\section{DAFTAR PUSTAKA}

Afrely, R. W., Rosyidih, M. I., dan Fajariyah, S. 2015. Keanekaragaman Jenis Holothuroidea di Zona Intertidal Pantai Pancur Taman Nasional Alas Purwo. Jurnal ILMU DASAR, 16(1) : 23-28

Agusta, R. O., Sulardiono, B., dan Rudiyanti, S. 2012. Kebiasaan makan teripang (Echinodermata: Holothuridae) di perairan Pantai Pulau Pramuka, Kepulauan Seribu. J. of Management of Aquatic Resources, 1(1):1-8.

Anderson, S. C., Flemming, J. M., Watson, R., and Lotze, H. K. 2011. Serial exploitation of global sea cucumber fisheries. Fish and Fisheries 12: 317339.

Darsono, P. 2007. Teripang (Holothuridae): kekayaan alam dalam keanekaragaman biota laut. J. Oseana, (2):1-10.

Dolorosa, R. G, and Galon F. D. 2014. Species Ricnhness Of Bivalves And Gastropods In Iwahig River Estuary, Palawa, The Philippines. International Journal Of Fisheries And Aquatic Studies. 2(1) :207-215.

Hair, C. A., Pickering, T. D., and Mills, D. J. 2012. Asia-Pacific Tropical Sea Cucumber Aquaculture: Proceedings of an International Symposium Held in Noumea, New Caledonia, 15-17 February, 2011. Australian Centre for International Agricultural Research, Noumea, New Caledonia, 209 pp.

Handayani, T., Sabariah, V., dan Hambuako, R.R. 2017. Komposisi Spesies Teripang (Holothuroidea) di Perairan Kampung Kapisawar Distrik Meos Manswar Kabupaten Raja Ampat. Jurnal Perikanan Universitas Gadjah Mada 19 (1): 45-51

Kementerian Kelautan dan Perikanan. 2020. Statistik Ekspor : Hasil Perikanan Tahun 2015-2019. Direktorat Jenderal Penguatan Daya Saing Produk Kelautan dan Perikanan : Jakarta

Krebs, C. J. 1989. Ecology The Experiment Analysis of Distribution and Abundance. Harper and Row Publisher. New York. 
Lee, M. H., Kim, Y. K., Moon, H. S., Kim, K. D., Kim, G. G., Cho, H. A., Yoon, N. Y., Sim, K. B., Park, H. Y., Lee, D. S., Lim, C. W., Yoon, H. D., and Han, S. K. 2012. Comparison on proximate composition and nutritional profile of red and black sea cucumbers (Apostichopus japonicus) from Ulleungdo (Island) and Dokdo (Island), Korea. Food Science Biotechnology 21 : 1285-1291 https://doi.org/10.1007/s10068-012$\underline{0169-z}$

Odum, E. P. 1993. Dasar-dasar Ekologi. Fundamental of Ecology. Gajah Mada University Press. Yogyakarta

Oedjoe, M. D. R., dan Eoh, C. B. 2015. Keanekaragaman Timun Laut (Echinodermata: Holothuroidea) Di Perairan Sabu Raijua, Pulau Sabu, Nusa Tenggara Timur. Jurnal IImu dan Teknologi Kelautan Tropis, 7 (1) : 309-320

Purcell, S. W., Mercier, A., Conand, C., Hamel, J. F., Toral-Granda, M. V., and Lovatelli, A., and Uthicke, S. 2013. Sea cucumber fisheries: global analysis of stocks, management measures and drivers of overfishing. Fish and Fisheries 14: 34-59. Doi : $\quad$ https://doi.org/10.1111/j.14672979.2011.00443.x

Radjab, A. W., Rumahenga, S. A., Soamole, A., Polnaya, D., dan Barends, W. 2014. Keragaman dan kepadatan ekino-dermata di periaran Teluk Weda, Maluku Utara. J. IImu dan Teknologi Kelautan Tropis, 6(1):17-30.

Ru, X., Zhang, L., Li, X., Liu, S., and Yang, H. 2018. Development strategies for the sea cucumber industry in China. Journal of Oceanology and. Limnology. 37, 300-312. https://doi.org/10.1007/s00343-0197344-5
Sukmiwati, M., Salmah, S., Ibrahim, S., Handayani, D., dan Purwati, P. 2012. Keanekaragaman Teripang (Holothuroidea) di Perairan Bagian Timur Pantai Natuna Kepulauan Riau. Jurnal Natur Indonesia 14(2) : 131137

Woo, S. P., Yasin, Z., Ismail, S. H. and Tan, S. H. 2013. The distribution and diversity of sea cucumbers in the coral reefs of the South China Sea, Sulu Sea and Sulawesi Sea. Deep-Sea Research II, http://dx.doi.org/10.1016/j.dsr2.2013.0 4.020

Wen, J., Hu, C., and Fan, S. 2010. Chemical composition and nutritional quality of sea cucumbers. Journal of the Science of Food and Agriculture 90: 2469-2474.

Xia, S. D., and Wang, X. Y. 2015. Nutritional and medicinal value. In : Yang $\mathrm{H} \mathrm{S}$, Hamel J F, Mercier A eds. The Sea Cucumber Apostichopus Japonicus : History, Biology and Aquaculture. Academic Press, Amsterdam, The Netherlands. p.353-365.

Yang, H. S., and Bai, Y. C. 2015. Apostichopus Japonicus in the life of chinese people. In : Yang H S, Hamel J F, Mercier A eds. The Sea Cucumber Apostichopus Japonicus : History, Biology and Aquaculture. Academic Press, Amsterdam, The Netherlands. p.1-23.

Yang, H., Hamel, J-F., and Mercier, A. 2015. The Sea Cucumber Apostichopus japonicus. History, Biology and Aquaculture. Academic Press (Elsevier), Salt Lake City, UT, $437 \mathrm{pp}$.

Yusron, E. 2016. Struktur Komunitas Ekhinodermata (Asteroidea, Ophiuroidea, Echinoidea Dan Holothuroidea) Di Perairan Taman Nasional Wakatobi Sulawesi 
Tenggara. Jurnal IImu dan Teknologi Kelautan Tropis, 8(1) : 357-366

Zamora, L. N., Yuan, X., Carton, A. G., and Slater, M. J. 2016. Role of deposit- feeding sea cucumbers in integrated multitrophic aquaculture: progress, problems, potential and future challenges. Reviews in Aquaculture 0, $1-18$ doi: $10.1111 /$ raq. 12147 